\title{
O ARMATĂ, DOUĂ SISTEME. JUSTIŢIA MILITARĂ ÎN TRANSILVANIA, ÎN A DOUA CAMPANIE A RĂZBOIULUI DE ÎNTREGIRE 1918-1920
}

\author{
ONE ARMY, TWO SYSTEMS. MILITARY JUSTICE IN TRANSYLVANIA, \\ DURING THE SECOND CAMPAIGN OF THE WAR \\ OF REUNIFICATION 1918-1920
}

\author{
Col. (r) prof.univ.dr. Ion GIURCÄ* \\ Col.drd. Liviu CORCIU**
}

\begin{abstract}
În plină campanie de eliberare a Transilvaniei, Consiliul Dirigent din Sibiu a hotărât să sprijine efortul armatei române și a dispus înființarea unui Comandament General Teritorial, cu misiunea de a începe recrutarea în Ardeal, în Banat și în ținuturile românești din Ungaria, pentru constituirea unor unităti de voluntari. Mai târziu, din rândul acestora, au fost înființate Corpurile 6 și 7 armată, recrutate exclusiv dintre ardeleni, indiferent de naționalitate. În baza Decretului I al Consiliului Dirigent, legile, ordonanțele, regulamentele și statutele legale emise înainte de 18 octombrie 1918, data proclamării independenţei Transilvaniei faţă de Budapesta, au rămas provizoriu în vigoare. În acest context, militarii diviziilor ardelene erau supuşi jurisdicției militare, în baza Codului penal militar austro-ungar din 1855, în timp ce militarii armatei române care acționau sub comanda Comandamentului Trupelor din Transilvania se aflau sub jurisdicția legilor românești, implicit a Codului de justiție militară.

In the middle of the campaign for Transylvania's liberation, the Governing Council of Sibiu had decided to support the efforts of the Romanian army and ordered the establishment of a Territorial General Commandment meant to begin recruitment in Transylvania, Banat and the Romanian provinces in Hungary, in order to constitute an unit of volunteers. Ulteriorly, out of their ranks, 6th and 7th Army Corps have been established, recruited exclusively from Transylvanians regardless of their nationality. Under Decree I passed by the Governing Council of Sibiu, laws, ordinances, regulations and legal statutes issued prior to December 18th1918, when Transylvania was proclaimed independent of Budapest, were temporarily in force. Within this context, militaries of Transylvanian divisions were subject to military jurisdiction under Austro-Hungarian Military Criminal Code of 1855, whereas Romanian militaries who were under the command of Transylvanian Commandment of Troops were subject to the jurisdiction of Romanian laws, implicitly to the Code of military justice.
\end{abstract}

Cuvinte-cheie: justiție militară; disciplină; insubordonare; curte marțială; campanie.

Keywords: military justice; discipline; disobedience; court martial; campaign.

Subiectul abordat în lucrarea de față nu este specific numai organismului militar, ci întregii legislații din teritoriile românești, unite ca urmare a deciziilor de la Chișinău, Cernăuți și Alba Iulia. La momentul realizării Marii Uniri, în Vechiul Regat, erau în vigoare Codul penal și cel de procedură penală din 1864, în Transilvania, Codul Penal maghiar din 1878 și Codul de procedură penală din 1896, în Basarabia, Codul penal rusesc din

\footnotetext{
*Universitatea Națională de Apărare „Carol I” e-mail: ion_giurca@yahoo.fr

**Arhivele Militare Naționale Române

e-mail:liviu.corciu@yahoo.com
}

1903 și Codul de procedură penală din 1864, iar în Bucovina, Codul penal austriac din 1852 și Codul procesual din $1873^{1}$.

Vom încerca să prezentăm în continuare, așa după cum am descoperit în documentarea noastră, legăturile dintre neconcordanţele legislative din Vechiul Regat și teritoriile unite, lipsa de încadrare cu personal specializat a curților marțiale și starea disciplinară a unora dintre unitățile de voluntari din compunerea diviziilor ardelene, în campania pentru apărarea Marii Uniri.

În conformitate $\mathrm{cu}$ prevederile armistiţiului, semnat la Belgrad, la 31 octombrie/13 noiembrie 1918, pe cursul Mureșului fusese stabilită o linie de demarcație care parcurgea o linie sinuoasă, de 
la Munții Rodnei, în nord, trecând prin Bistrița, Târgu-Mureș, Alba Iulia, Deva, pe la sud de Arad, și mai departe spre vest, spre Szeged și Pecs, linie care trasa limitele până la care armata română putea avansa în Transilvania.

Cele dintâi acțiuni militare în Transilvania au fost desfășurate de subunități din compunerea Comandamentului Corpului de grăniceri, începând cu data de 29 octombrie/11 noiembrie 1918, cu misiunea de a asigura concentrarea ${ }^{2}$, la vest de Munții Carpaţi, a forțelor principale, formate din Divizia 7 infanterie și Divizia 1 vânători.

Primele elemente de valoarea unui regiment de infanterie întărit din Divizia 1 vânători, comandată de generalul Aristide Lecca, respectiv, din Divizia 7 infanterie, comandată de generalul Traian Moșoiu, ardelean de origine, au trecut Carpaţii în zilele de 10-23 noiembrie și 11-24 noiembrie 1918, cu misiunea de a constitui un aliniament operativ de acoperire pe cursul Mureșului, și s-au concentrat $^{3}$ spre izvoarele Mureșului, în zona Toplița-Ditrău-Gheorghieni, respectiv, izvoarele Oltului, în zona Sândominic-Dănești-MiercureaCiuc.

Fără a întâmpina o rezistență serioasă, la 17-30 noiembrie 1918 elemente înaintate ale Diviziei 7 infanterie au intrat în Reghin, iar două zile mai târziu, în Târgu-Mureș; la 17-30 noiembrie 1918 Regimentul 1 vânători a ocupat Miercurea-Ciuc, iar în aceeași zi, Regimentul 6 vânători a ocupat Braşovul.

Ulterior, ca urmare a încălcării de către unguri a prevederilor Convenției de armistițiu de la Belgrad, la 29 noiembrie/12 decembrie 1918 Marele Cartier General român a solicitat ${ }^{4}$ Comandamentului Armatei de Dunăre acordul Puterilor Aliate, de a depăşi linia de demarcație, stabilită pe cursul Mureșului, atât pentru a răspunde apelului Consiliului Dirigent, care solicitase o intervenție imediată, cât și pentru a contracara reorganizarea și concentrarea forțelor ungare la adăpostul liniei de demarcaţie, și pentru a împiedica astfel răspândirea şi propagarea ideilor anarhiste.

In acest context, Marele Cartier General a transmis Comandamentului Trupelor din Transilvania, constituit la 11/24 decembrie 1918, ordinul de a ocupa toate ținuturile românești care au făcut parte din fosta monarhie austro-ungară, cu excepția Banatului, ocupat de către trupele franceze și sârbe, pentru a asigura ordinea, viața și avutul locuitorilor. În data de 11/24 decembrie 1918, ostașii Diviziei 7 infanterie intrau în Cluj, iar la Sibiu, generalul Traian Moșoiu era primit ca un erou.

Pe lângă toate comandamentele de divizii remobilizate și înființate, avea să se înființeze, începând din luna ianuarie 1919, curți marțiale, pentru a se sancționa toate încălcările prevederilor legilor și regulamentelor militare.

\section{Gărzile naționale}

Unităţile armatei române recrutate în Transilvania, cunoscute sub denumirea de divizii ardelene, au fost precedate de gărzile naționale, a căror înființare a început ${ }^{5}$ încă din 18-31 octombrie 1918 și a continuat în cursul lunilor noiembrie și decembrie. La nivel rural, gărzile erau structurate pe principiul teritorial, în fiecare comună cu majoritate românească înființându-se o gardă naţională, cu cerința expresă ca efectivele să nu depășească $5 \%$ din populația comunei.

Gărzile nu aveau uniforme speciale, ci foloseau fie vechea uniformă a armatei austro-ungare, fie haine civile, având însă obligația de a purta o brasardă tricoloră la brațul stâng, pe care era scris „Garda naţională română”.

Eficiența acestor structuri, care ajunseseră, către sfârșitul lunii noiembrie 1918, la un efectiv de aproximativ 8.000-10.000 de oameni, a fost dovedită în apărarea libertății de mișcare a delegaților la Marea Adunare Națională de la Alba Iulia, când au eliberat, prin forța armelor, nodurile de cale ferată de la Cucerdea, Teiuș, Podul Mureș și Coșlar, care fuseseră ocupate de trupe secuiești. În același timp, peste 3.000 de membri ai Gărzilor naționale au asigurat ordinea și siguranța delegaților în Alba Iulia 6 .

Astfel, după ce avântul generat de sentimentul național s-a mai temperat, printr-o hotărâre ${ }^{7}$ a Resortului Apărării și Siguranței Publice din cadrul Consiliului Dirigent din 9/22 decembrie 1918, s-a trecut la desființarea treptată a gărzilor naționale românești în teritoriile eliberate, care deveniseră $u n$ pericol, după cum era consemnat într-un raport ${ }^{8}$ al Comandamentului Trupelor din Transilvania, deși fuseseră de mare folos la început, în entuziasmul revoluției.

Gărzile naționale au fost înlocuite cu trupe specializate de jandarmi și poliție, deși constituirea acestora a fostun proces de durată. Dealtfel, teritoriul 
Transilvaniei suferea la capitolul organizare, mai ales din cauza faptului că majoritatea administraţiei fusese încadrată cu funcționari de origine maghiară, care se retrăseseră odată cu vechea stăpânire.

De aceea Consiliul Dirigent a făcut un apel ${ }^{9}$ la ofițerii și ostaşii de toate gradele, de origine română, care au activat în fosta armată austroungară, fiind astfel organizate 15 companii ale jandarmeriei ardelene, care au primit sarcina de a dezarma populația și de a înlocui gărzile naţionale locale. Din aceste efective, au fost constituite, mai târziu, primele regimente ardelene de jandarmi, cu sediile la Brașov, Cluj și Arad, care au început să înlocuiască treptat trupele operative în serviciile pentru menținerea ordinii și pentru paza căilor de comunicații în interiorul Transilvaniei.

În armata austro-ungară, cu o structură complexă și caracter multinațional ${ }^{10}$, regimentele 30,63 și 64 infanterie erau exclusiv românești, la acestea adăugându-se alte 13 regimente, în care ponderea românilor era de peste $50 \%$ din efective, însumând, la începutul războiului, 72.000 de militari ${ }^{11}$.

Ulterior, în anul 1915, efectivele de naționalitate română care încadrau unități ale armatei austroungare se ridicau la 200.000-300.000 de militari, care au participat în campania de pe frontul de est, în Galiția, dar și pe frontul balcanic și pe cel italian, fiind elogiați atât în comunicatele oficiale, cât și de presa maghiară.

Intr-un articol publicat, la 18/31 august 1915, în ziarul Adevărul de către publicistul Ion Grecu, intitulat „Regimentele românești condamnate la moarte. Ce înseamnă laudele ungurești", a fost prezentat publicului traseul de luptă al unora dintre aceste regimente, lăudate de presa maghiară, în opinia autorului, numai după ce fuseseră „topite” prin asalturi fără număr împotriva tunurilor rusești: „Căci presa ungurească (...) laudă soldații români numai după ce-s morți (...). Lauda ungurească la adresa unui regiment românesc înseamnă că un nou regiment este condamnat să moară și că executarea sentinței a început"12.

De altfel, vitejia soldaţilor de naţionalitate română înrolați în armata austro-ungară era recunoscută și de autoritățile imperiale, Regimentul 50 din Alba Iulia fiind singurul din întreaga monarhie dualistă care purta, pe drapel, medalia de aur, iar pentru contribuția sa la campania din Galiția, drapelul regimentului a fost decorat de împăratul Wilhelm al II-lea cu „Crucea de fier”"13.

\section{Înființarea diviziilor ardelene}

Concomitent cu acțiunile armatei române în Transilvania, Consiliul Dirigent a hotărât să sprijine efortul eliberator și a dispus înființarea ${ }^{14}$ la Sibiu, la 5/18 ianuarie 1919, a Comandamentului general teritorial (întâlnit în unele documente sub denumirea de Comandamentul teritorial A.B.U., s.n.), sub comanda generalului Ioan Boeriu, cu misiunea de a începe recrutarea în Ardeal, în Banat și în ținuturile românești din Ungaria, în vederea constituirii unor unități de voluntari ardeleni.

Aproximativ în aceeași perioadă, în baza „Decretului-Lege nr. 345”, din 25 ianuarie/2 februarie 1919, aprobat sub rezerva ratificării ulterioare a corpurilor legiuitoare, s-a luat hotărârea înființării Corpurilor 6 și 7 armată, cu diviziile $16,17,18,19,20$ și 21 , recrutate exclusiv dintre ardeleni ${ }^{15}$.

Actul normativ fusese iniţiat la propunerea ministrului de război din acea vreme, generalul de corp de armată Arthur Văitoianu, și avea menirea de a reglementa dreptul și îndatorirea ardelenilor de a exercita serviciul militar, urmărind în același timp aplicarea organizării militare românești întrun teritoriu nou, a principiilor legilor de organizare şi recrutare, precum și a celor referitoare la poziţia ofițerilor, drepturi de soldă, căsătorie, pensii etc.

Deși prevederile art. 2 din ,Decretul-Lege nr. 345" stabilea că toate regulamentele și toate legile românești cu caracter militar erau aplicabile și acestor unităţi, legiuitorul pare să fi ținut cont de realitatea obiectivă a situației, luând în calcul și o anumită stare de tranziţie, ce urma să fie reglementată prin decizii ministeriale.

Realitatea obiectivă a situaţiei ținea atât de necunoașterea legilor de către cei vizați, cât și de nevoia de interoperabilitate a noilor structuri, de faptul că majoritatea voluntarilor proveneau dintre foștii prizonieri de război de pe fronturile din Serbia, Italia ori Galitiia. La cele de mai sus, se mai adăugau lipsa de instruire a ofițerilor și trupei după regulamentele din Vechiul Regat, precum și barierele de limbă, având în vedere că trupa urma a se recruta din rândul mai multor naționalități, cu excepția celei maghiare.

În vederea punerii în aplicare a ,DecretuluiLege nr. 345”, a fost emisă „Decizia ministerială nr. 40", care stabilea constituirea, în primă fază, doar a diviziilor 16 și 18 infanterie, precum și modalitatea de încadrare cu ofițeri combatanți și 
necombatanți, compunerea organică a corpurilor de trupă, armamentul, muniţia și echipamentul care trebuiau distribuite etc. ${ }^{16}$

Comandant al Diviziei 16 infanterie a fost numit Alexandru Hanzu, fost colonel în armata austriacă, originar din Sălişte, jud. Sibiu, care a primit gradul de general al Armatei Române, la data de 11 aprilie 1919.

La Divizia 18 a fost numit comandant Dănilă Papp, fost colonel în Marele Stat Major austriac, profesor la Academia Militară din Viena și remarcabil comandant pe frontul rusesc ${ }^{17}$, originar din jud. Bihor, avansat, la rândul său, la gradul de general al Armatei Române, la data de 11 aprilie 1919.

Justiția militară în cele două divizii, conform art. 9 din „Decizia nr. 40”, urma a se administra, conform Codului de justiţie militară românesc, de către instanțele de justiție militară, organizate după modelul celor din armata română, dar cu aplicarea unor măsuri impuse de perioada de tranziţie.

Pentru a se pune în practică prevederile celor două norme prezentate mai sus, la 1 martie 1919 a luat ființă, la Sibiu, Serviciul Organizare a corpurilor 6 și 7 armată (SO 6-7, s.n.) sub conducerea generalului Ioan Boeriu, subordonat direct Ministerului de Război, cu misiunea de a coordona activitățile de mobilizare, echipare și instruire ale diviziilor ardelene, dar care viza și organizarea militară unitară a Ardealului, Banatului și Maramureșului ${ }^{18}$.

Până la 27 martie 1919, mobilizarea unităților diviziilor 16 și 18 infanterie a fost încheiată în linii mari, efectivele lor cuprinzând, pe lângă voluntari sosiţi în anul 1917 și pregătiţi în Moldova, și numeroși militari din fosta armată austro-ungară, demobilizați, în urma armistițiului de la Villa Giusti.

Structura acestor divizii era aproape identică cu cea a diviziilor de infanterie existente în organica armatei române, având în compunere regimente de infanterie, de artilerie, batalioane de vânători și de pionieri, precum și câte un spital de campanie.

Dislocarea în garnizoanele de pace ale unităților Diviziei 16 infanterie era următoarea: Regimentul 81 infanterie la Dej, Regimentul 82 infanterie la Târgu-Mureș, Regimentul 83 infanterie la Cluj, Regimentul 84 infanterie la Bistrița. Acestora li se mai adăugau unități de artilerie și un batalion de vânători, în total 10.590 de oameni ${ }^{19}$.
Divizia 18 infanterie avea dislocat Regimentul 89 infanterie la Brașov, Regimentul 90 infanterie la Sibiu, Regimentul 91 infanterie la Alba Iulia, Regimentul 92 infanterie la Orăștie, la care se mai adăugau unități de artilerie, un batalion de pionieri și un batalion de vânători, în total 11.210 de oameni ${ }^{20}$.

Ca urmare a evoluției îngrijorătoare a situației pe frontul din Transilvania, în contextul în care, la 25 martie 1919, noul guvern de la Budapesta declarase război tuturor vecinilor, Marele Cartier General a ordonat S.O.6-7 să mobilizeze cele două divizii, cu începere de la 1 aprilie 1919, urmând ca, într-un interval de 10 zile, acestea să fie puse la dispoziţia comandamentelor operative ${ }^{21}$.

Astfel, la 1 aprilie 1919, Diviziile 16 și 18 infanterie au ieșit din subordonarea S.O.6-7, fiind direct subordonate operativ și administrativ Comandamentului Trupelor din Transilvania, respectiv, Marelui Cartier General, urmând să primească misiuni și să desfășoare acțiuni militare, alături de unitățile din Vechiul Regat ${ }^{22}$.

\section{O armată, două sisteme de justiție militară}

Diviziile 16 și 18 infanterie au plecat în zona de operații, având în structură ofițeri de justiție militară pentru aplicarea legilor conform prevederilor „Decretului-Lege nr. 345”, din 25 ianuarie/7 februarie1919, mai precis conform regulamentelor și legilor românești cu caracter militar, în momentul în care unitățile subordonate Comandamentului Trupelor din Transilvania se aflau pe aliniamentul Munților Apuseni. O curte marțială ${ }^{23}$ fusese creată și pe lângă S.O. 6-7, dar care funcționa după legile ungurești ${ }^{24}$, iar de activitatea acesteia din urmă generalul Gheorghe Mărdărescu, comandantul Comandamentului Trupelor din Transilvania, nu era foarte mulțumit, de fapt chiar a solicitat încadrarea acesteia numai cu ofițeri din regat cu experiență juridică, „,ăci așa cum merg lucrurile la acel serviciu, lasă excesiv de mult de dorit" ${ }^{\prime 25}$.

Situația era cunoscută, întrucât încă din 5 februarie 1919, în calitatea sa de atunci, de comandant al Comandamentului general teritorial, subordonat Consiliului Dirigent, generalul Ioan Boieriu se adresase Ministerului de Război prin raportul cu nr. 44, din 18 februarie 1919, și semnalase acest fapt și Consiliului Dirigent ${ }^{26}$. Practic, în baza „Decretului I” al Consiliului Dirigent Român, 
intitulat „Decret despre funcționarea în $\bmod$ provizoriu a serviciilor publice, aplicarea legilor, despre funcționari și întrebuințarea limbilor", legile, ordonanțele, regulamentele și statutele legale, emise înainte de 18/31 octombrie 1918, data proclamării independenţei Transilvaniei față de Budapesta, rămăseseră provizoriu în vigoare, ,,în interesul ordinii publice și pentru a asigura continuitatea de drept"27.

Astfel, conform celor consemnate în raport, militarii diviziilor ardelene în curs de constituire erau supuşi jurisdicției militare, în baza Codului penal militar austro-ungar, promulgat la 15 ianuarie 1855. La prevederile acestuia, se mai adăugau articolul de lege ungar XXI ex. 1890, referitor la pedepsirea nesupunerii faţă de ordinul de chemare sub drapel și a seducerii la o astfel de infracțiune, articolul de lege ungar XXX ex. 1912, privind dispozițiile penale ale legii asupra puterii armate şi ale altor legi privitoare la împlinirea îndatoririi serviciului militar, precum și articolul de lege ungar XXXII ex. 1912, cu privire la procedura penală militară.

Raportul nu a determinat nicio schimbare în atitudinea Consiliului Dirigent, care, în mod consecvent, a emis la 21 februarie 1919 „Ordinul despre justiția militară nr. 30301”, prin care reglementa modul în care urma să se administreze justiția militară în întreg teritoriul ,alipit” Vechiului Regat (Ardeal, Banat și ținuturile românești din Ungaria, s.n.) $)^{28}$, supus, din punctul de vedere al administrării militare, Serviciului Organizare 6, 7.

Astfel, la Sibiu urma a se forma un tribunal militar, având jurisdicție asupra tuturor militarilor supuși S.O. 6, 7, precum și asupra persoanelor civile care, în baza legilor existente, erau justiţiabile din partea forurilor judecătorești militare.

Ordinul mai preciza faptul că, dată fiind starea de mobilizare, tribunalul urma procedura de campanie, în baza capitolului XXVII al procedurii penale militare din legea ungară, atribuțiile procesuale ale eșalonului superior avându-le comandantul S.O. 6, 7.

De asemenea, ordinul stabilea o filială la Cluj a tribunalului militar din Sibiu, cu competență în soluționarea cauzelor care priveau trupele din comitatele Cluj, Mureș și Solnoc-Dăbâca ${ }^{29}$, și înființa câte un arest militar în garnizoanele Cluj și Sibiu.

Subliniem că, în conformitate cu art. 59 din Codul penal militar al fostei armate austro-ungare ${ }^{30}$, arestul la închisoarea de garnizoană se aplica trupei, până la gradul de sergent, militarilor cărora li se aplicase pedeapsa accesorie a degradării militare, soțiilor și copiilor tuturor celor menționați anterior, precum și persoanelor civile, pentru fapte aflate în competența justiţiei militare.

Durata minimă a arestului era de 24 de ore, iar durata maximă de 6 luni, existând și situații speciale când se putea depăși acest termen. De asemenea, conform art. 77 din același Cod penal militar, pedepsei cu arestul i se puteau adăuga, concomitent, mai multe ,agravări”, precum postul, în care cel pedepsit era hrănit mai multe zile numai cu pâine și apă, aşternutul vârtos, nu mai mult de două ori pe săptămână, inchiderea într-o celulă intunecoasă, nu mai mult de 14 zile continuu, munca în cazarmă sau în tabără etc.

Revenind la modul de aplicare a justiţiei militare în campania din Transilvania, mai precis la existența simultană și specifică fiecărei entități legiuitoare, în baza legislației aplicabile pe teritoriul său, atât din Transilvania, cât și din Vechiul Regat, a propriului cadru de reglementare în domeniu, generalul Ioan Boeriu a iniţiat un nou demers. De această dată, odată cu apariţia „Decretului-Lege nr.345", din 25 ianuarie/7 februarie 1919, și a emiterii de către Ministerul de Război a „Deciziei nr. 40", din 20 ianuarie/2 februarie 1919, pe care le-am prezentat mai sus, acesta s-a adresat Consiliului Dirigent, prin „Raportul nr. 11442”, din 21 aprilie 1919, informând Resortul de Justiţie din compunerea acestuia că există neconcordanțe cu privire la administrarea justiției militare la trupele și formațiunile armatei române întregite ${ }^{31}$, între prevederile ,Decretului I”, din 24 ianuarie/6 februarie 1918, și prevederile „Decretului-Lege nr. 345”, respectiv, ale „Deciziei nr. 40”.

Generalul Ioan Boeriu a informat Consiliul Dirigent cu privire la cadrul legal aplicabil în ceea ce privește justiţia militară, confirmând acordul prealabil al Marelui Cartier General, comunicat șefului de stat major al Comandamentului general teritorial, de la acea vreme, colonelul Dănilă Papp, ca diviziile ardelene, în starea lor operaţională iniţială, să-și poată constitui curți marțiale proprii.

Explicând Consiliului Dirigent posibilitatea ca diviziile ardelene, acționând împreună cu diviziile din Vechiul Regat, după cum le cer interesele operative, să subordoneze unele dintre aceste unități și viceversa, generalul Ioan Boeriu întreba 
dacă „,este bine și eficace ca la Diviziile ardelene în zona de operații justiția penală să se deie după alte legi ca și la diviziile din vechiul regat?"32.

Din explicațiile acestuia, reieșea incompatibilitatea cadrului legislativ, în ceea ce privește administrarea justiției militare atât sub aspectul competenței, cât și al procedurii penale. Justiția penală în procedura de campanie, conform articolului XXXII din legea austro-ungară, era în competența comandantului de divizie sau de corp de armată, prin ofițerii de justiție care îi erau desemnați, situație în care soldaţii din Vechiul Regat, ajunși în cursul operațiunilor sub ordinele comandantului unei divizii ardelene, ar fi trebuit judecaţi după legile fostei armate austro-ungare, ceea ce ar fi reprezentat o încălcare a principiilor Constituţiei din România.

Nici din punctul de vedere al procedurii penale, lucrurile nu stăteau diferit, având în vedere cel puțin doi factori. Cel dintâi, procedura penală militară a armatei austro-ungare nu avea nicio cale de atac, pe când în procedura Codului de justiție militară românesc exista calea recursului la Consiliul permanent de revizie. Argumentul era veridic, de vreme ce dispozițiile ,Înaltului Decret Regal nr. 2930", din 16/29 septembrie 1916, respectiv ale „Inaltului Decret Regal nr. 7”, din 7/20 ianuarie 1917, prin care dreptul la recurs fusese suspendat, respectiv, ridicat, fuseseră abrogate prin Legea nr. 2254, din 28 august $1918^{33}$.

Cel de-al doilea factor ținea de procedura în sine, mai precis de faptul că, în situaţia în care comandantul competent ar fi înaintat o sentință, considerată de acesta ca fiind ilegală, eșalonului superior spre a fi casată, conform procedurii penale militare a fostei armate austro-ungare, această atribuție procesuală ar fi revenit comandantului Comandamentului Trupelor din Transilvania, pus astfel în situația de a aplica o lege străină, aspect interzis de aceeași Constituție.

„Propun deci, încheia raportul său generalul Ioan Boeriu, decretarea ca justiţia militară la diviziile și unitățile unitare ardelene aflătoare în zona de operație, (...) justiția militară penală să se deie conform legilor din regat, iar la celelalte trupe ardelene, respectiv trupele aflătoare în afară de zona de operație, precum și față de persoanele civile supuse jurisdicțiunii militare din acest teritoriu, să se aplice legile decretate de consiliul dirigent" ${ }^{\prime 4}$.
Deși Consiliul Dirigent lăsase în textul „Decretului I" posibilitatea unor derogări, explicând că legile, ordonanțele, regulamentele și statutele legale emise înainte de 18 octombrie 1918 rămâneau în vigoare provizoriu, ,cu excepțiunile cuprinse în prezentul decret, și în alte decrete ce se vor da", nu au survenit modificări de substanță şi nici nu au fost notificate excepții în ceea ce privește administrarea justiției militare. Colegiul Dirigent a perseverat în menținerea unei jurisdicții și proceduri proprii asupra diviziilor ardelene, deși oportunităţi de armonizare legislativă par totuși să fi existat.

Concret, un alt proiect care a fost iniţiat de generalul Ioan Boeriu, prin care solicita modificarea limitelor de valori la infracțiunile ,provenite din râvna de câștig" "35, motivând că fuseseră stabilite în anul 1895, la promulgarea Codului penal militar austro-ungar şi că nu mai corespundeau referinţelor economice și sociale din anul 1919, a fost adoptat de Consiliul Dirigent prin „Decretul nr. XIII”, din 20 mai 1919, intitulat „Decret despre modificarea unor dispoziții ale codului penal militar austro-ungar, sancționat în 15 ianuarie 1855, și ale procedurei penale militare aplicabile la armate teritorială română din Transilvania, Banat și Ținuturile românești din Ungaria"36. Singura modificare adusă administrării justiţiei militare, prin intermediul acestui nou decret, a fost ca sentințele emise de către curțile marțiale ale diviziilor ardelene să nu se mai pronunțe ,în numele împăratului”, ci ,în numele legii”.

\section{Starea disciplinară în diviziile ardelene}

Incertitudinea legislativă și procedurală pentru diviziile ardelene s-a repercutat și în starea disciplinară a unora dintre unitățile nou înființate, mai ales că ideile revoluției bolșevice bulversau nu numai Ungaria, dar și întreg continentul european și, în mod firesc, atinseseră și soldații de origine română din fosta armată austro-ungară.

Starea morală, materială și disciplinară a trupelor ardelene, dislocate în garnizoanele din zona interioară, a fost zugrăvită într-un raport al generalului Ioan Boeriu, adresat Comandamentului Trupelor din Transilvania, referitor la un incident în care soldaţi din Regimentul 81 infanterie maltrataseră câțiva jandarmi: „(...) Majoritatea acestor elemente sunt soldaţi reîntorși din captivitatea rusească, care au trecut și prin revoluția 
maghiară fiind infiltrați de porniri dușmănoase puterii statului. Dispoziţia lor pentru răzvrătire este nutrită și prin împrejurările deplorabile în care se află soldații din această garnizoană (garnizoana Dej, s.n.) majoritatea sunt desbrăcaţi, desculți și fără aşternut de noapte (...)"37.

Starea de spirit nu era cu mult diferită nici la trupele diviziilor 16 și 18 infanterie, dislocate în zona de operații. Printr-o telegramă adresată Comandamentului Trupelor din Transilvania, generalul Traian Moșoiu informa, la 23 aprilie 1919, că trupele ardelene din unele unități ale diviziilor 16 și 18 infanterie manifestă lipsă de disciplină, fără ca ofițerii acestor unități ,să poată avea forța morală și materială a-i împiedica"38.

Pentru a înlătura acest rău, care, în opinia sa, reprezenta ,germenul dezordinei”, generalul Traian Moșoiu propunea ca, la fiecare divizie, să se atașeze câte un detașament de jandarmi din țară, sub conducerea a cel puțin 3-4 ofițeri de jandarmi energici, care să poată reprima imediat orice abuz.

În aceeași zi, tot printr-o telegramă, a fost comunicată și rezoluția generalului Gheorghe Mărdărescu: „Se va da ordin să raporteze imediat de măsuri ce s-au luat. Fac răspunzători direct pe comandanţii de divizii de alunecarea pe această pantă. Curțile marțiale și ele trebuie să funcționeze și să reprime cu toată rigoarea aceste acte de sălbăticie" 39 .

Ca urmare, comandanții celor două divizii, prin „Ordinul nr. 5090”, din 25 aprilie 1919, au fost atenționați ${ }^{40}$, precizându-li-se că trupele din subordine lasă foarte mult de dorit din punctul de vedere al ordinii și disciplinei, și că aceste manifestări aduc o gravă atingere prestigiului și demnității armatei române.

De altfel, diviziile 16 și 18 infanterie fuseseră puse, încă de la 1 aprilie 1919, la dispoziţia Comandamentului Trupelor din Transilvania și plecaseră deja în zona de operaţii, după cum se consemna în raport, fiind încadrate cu ofițeri de justiție, pentru aplicarea justiției, conform legilor sus-numite (legile aplicate în fosta armată austroungară, s.n.).

Reacția generalului Dănilă Papp la acuzațiile aduse subordonaților săi nu a întârziat, astfel încât, la data de 28 aprilie 1919, acesta raporta situația generalului Gheorghe Mărdărescu ${ }^{41}$. Deși accepta că, în unele unități, unii dintre soldați săvârșiseră acte de indisciplină care erau în curs de instrumentare, în opinia comandantului Diviziei 18 infanterie, situația trupelor sale se înscria în comportamentul general al societății transilvănene a acelor vremuri. Aceasta traversa un vid de autoritate nu numai în administrație, ci în majoritatea sectoarelor vieții sociale, atât ca urmare a proclamării independenței față de Budapesta, cât și din cauza revoluției bolșevice, în plină desfășurare pe teritoriul maghiar.

Cât privește disciplina trupelor, deși se încercase mobilizarea lor graduală, avându-se în vedere disciplinarea acestora încă de la sosirea în unităţi, scria generalul Dănilă Papp, evenimentele operative au accelerat procesul. Prezentarea zilnică în unități a aproximativ 200-400 de recruți, dublată de lipsa ofițerilor, nu mai mulți de 20 la un regiment, dintre care mulți nu cunoșteau încă limba română, lipsa subofițerilor și nevoia de timp pentru a lua oamenii în mână au contribuit în egală măsură la situația în speță.

O altă cauză, susținea generalul Dănilă Papp, a fost solicitarea Comandamentului Trupelor din Transilvania, de implicare a peste 5.000 de oameni în misiuni de pază a căilor ferate, cu ocazia grevei din 15 martie 1919, misiune care a făcut ca instrucția să treacă într-un plan secundar. Acest aspect s-a reflectat și în starea de disciplină: „O disciplinare sistematică, care după starea morală a oamenilor ar fi fost necesară, nu s-au putut face și regimentele or pornit neînchegate la front. Cei care sunt vinovaţi vor primi întotdeauna pedeapsa meritată" ${ }^{\prime 2}$.

$\mathrm{Cu}$ toate aceste asigurări, la începutul lunii iulie 1919, deși aflată în dispozitiv pe râul Tisa, în apropiere de Szolnok, Divizia 18 infanterie încă nu avea un comisar regal, deși Comandamentul Trupelor din Transilvania telegrafiase Marelui Cartier General în vederea trimiterii unuia „sau cel puțin a unui substitut de comisar regal", după cum suna solicitarea, ,întrucât în prezent această curte nu poate funcționa, deoarece actualul comisar regal nu cunoaște legile" (românești, s.n.) ${ }^{43}$.

În lipsa unui ordin explicit, această telegramă ar putea fi considerată cea dintâi dovadă a faptului că Marele Cartier General nu acceptase o administrare duală a justiției militare ori, cel puțin, nu acceptase pentru diviziile 16 și 18, pe care le subordona prin Comandamentul Trupelor din Transilvania, și care fuseseră implicate, până la acel moment, în acțiuni militare, alături de trupele din Vechiul Regat.

Administrarea justiţiei militare la Divizia 18 infanterie pare să fi constituit totuși o problemă, 
de vreme ce, la 14 iulie 1919, Comandamentul Trupelor din Transilvania a telegrafiat din nou Marelui Cartier General, pentru a semnala faptul că, deși fuseseră transmise trei solicitări de încadrare a unui substitut de comisar regal la parchetul curții marțiale a Diviziei 18 infanterie, demersul rămăsese fără rezultat. Acest nou demers fusese iniţiat ca urmare a unei noi solicitări din partea generalului Dănilă Papp, care informase Comandamentul Trupelor din Transilvania, avertizând că, ,prin nefuncționarea justiției militare, disciplina este serios periclitată"44.

Convins, la rândul său, de caracterul urgent și de justețea argumentelor prezentate, generalul Gheorghe Mărdărescu accentua, adresându-se Marelui Cartier General, necesitatea repartizării a câte unui substitut de comisar regal la parchetele curților marțiale ale diviziilor 16 și 18 , care să îndrume lucrările, în caz contrar acestea neputând functiona.

Totuși, curtea marțială a Diviziei 16 infanterie funcționa, sau cel puțin așa reiese din ,Raportul nr. 710", din 26 iunie 1919, al generalului Gheorghe Mărdărescu, prin care acesta informa Marele Cartier General despre executarea sentinţelor de condamnare la moarte a trei militari, sergenții Gondosch Mihail și Boschzer Mihail, respectiv, soldatul Friss Nistor. Aceștia fuseseră judecați la data de 14 iunie 1919 de curtea marțială a Diviziei 16, găsiţi vinovați, pentru că ,,au agitat spiritele camarazilor, îndemnându-i a nu se mai supune legilor militare, a omorî pe ofițeri și a părăsi frontul" ${ }^{\prime 4}$, iar sentințele fuseseră comunicate tuturor diviziilor pentru a fi aduse la cunoștința trupelor sub arme.

La Divizia 16 infanterie, Comandamentul Trupelor din Transilvania solicitase, încă din 8 iunie 1919, Marelui Cartier General trimiterea unui comisar regal, împreună cu toate legile și regulamentele necesare, deoarece divizia raportase că, din cauza acestor lipsuri, curtea marțială nu putea funcționa în mod regulat ${ }^{46}$.

Cu toate aceste repetate solicitări, abia din 5 iulie 1919 Serviciul justiției militare din Marele Cartier General reușise să selecționeze câțiva ofițeri: pe locotenentul (r) Albert Lee și pe sublocotenentul (r) Ion Dumitrescu, pentru curtea marțială a Diviziei 16, respectiv, pe locotenentul (r) Constantin Bălescu, pentru curtea marțială a Diviziei 18 , dar ofițerii încă nu se prezentaseră, iar alți ofițeri licențiați și care să fi fost deja mobilizați nu erau disponibili ${ }^{47}$.

La curtea marțială a Diviziei 16 infanterie situația încadrării părea să fi fost mai bună, de vreme ce aceasta funcționa, încă din 5 iulie, după Codul de justiție militară al armatei române, după cum reiese dintr-o telegramă ${ }^{48}$, datată 20 august 1919, iar încadrarea era următoarea: căpitan Nicolae Negreanu, locotenent Albert Lee și sublocotenent Ion Dumitrescu. La 28 august 1919 personalul acesteia fusese completat cu căpitanul Aurel Bozac, fost auditor (comisar regal, s.n.) în armata austroungară, cu locotenentul Vasile Crăciun, magistrat stagiar, și cu sublocotenenții Alexandru Țandrău, Emil Furcaș și Valeriu Simonetti, toți trei studenți la drept ${ }^{49}$.

$\mathrm{Cu}$ toate acestea, se pare că rezultatele concrete întârziau să apară, de vreme ce, prin „Telegrama nr. 876”, din 7 octombrie 1919, șeful secției Justiție Militară din Marele Cartier General se adresa comandantului Diviziei 16 infanterie, atenționându-1 asupra nedestoiniciei personalului curții marțiale a diviziei sale, din cauza căreia: „mulţi pungași sunt pe punctul de a scăpa de pedeapsă $\breve{5}^{50}$.

În contextul în care, la 20 iulie 1919, începuse ofensiva Armatei Roșii ungare, care reușise să dezvolte mai multe capete de pod pe malul răsăritean al Tisei, Comandamentul Trupelor din Transilvania înainta Marelui Cartier General, prin „Telegrama nr. 8152”, din 22 iulie 1919, raportul nr. 778 al generalului Dănilă Papp, referitor la situația Diviziei 18 infanterie, unde nu domnea cea mai bună stare de spirit:,,(..) infanteria acestei divizii este complect demoralizată" ${ }^{51}$.

„Peste aceste trupe a trecut vântul revoluţiei, motiva $^{52}$ generalul Dănilă Papp, încercând să explice superiorilor cauzele acestei stări, distrugând și ultima rămășiță de disciplină din sufletul lor". Printre alte cauze care generaseră acea atitudine a trupelor, generalul Dănilă Papp a mai invocat lipsa timpului necesar pentru organizare și instrucție, după încheierea procesului de recrutare în regimente, trupele diviziei fiind aduse direct pe front, starea de oboseală a acestora, având în vedere că ardelenii erau în război de cinci ani, precum și lipsa unei motivaţii adecvate, prin faptul că regimentele diviziei acționau la vest de Tisa, „o regiune ce știu (soldaţii, s.n.) că nu va aparține lor" ${ }^{53}$. 
$\mathrm{Nu}$ în ultimul rând, comandantul Diviziei 18 infanterie menţiona că, într-o mare măsură, a contribuit și faptul că, până la data întocmirii raportului, 22 iulie 1919, nici măcar un caz de indisciplină nu fusese adus în fața curții marțiale a diviziei, care primise interdicție să judece după legile ungurești, iar personal care să cunoască legile și procedurile din Vechiul Regat nu sosise până în acel moment.

Situația disciplinară a trupelor din compunerea diviziilor ardelene părea să îngrijoreze Marele Cartier General, sau cel puțin așa poate fi interpretat „Ordinul nr. 9732”, din 24 iulie 1919. Aflat în inspecția trupelor din Transilvania, generalul Constantin Prezan a ordonat telegrafic Corpului II Armată să se trimită imediat diviziilor ardelene patru substituți de comisari regali, „dintre magistrații pricepuți, energici și cu experiență" ${ }^{54}$, fiindcă în lipsa unui personal competent, curțile marțiale ale celor două divizii nu puteau funcționa.

„Nu se poate pedepsi cum se cuvine, este consemnat în telegrama ${ }^{55}$ prin care a fost transmis ordinul, numeroasele cazuri de abateri de la datorie, furt, fugă de pe front, indisciplină, dezertări etc., care abundă în aceste divizii". Conform precizărilor din ordin, Corpul 2 Armată urma să selecționeze ofițerii în aceeași zi, conform criteriilor precizate, dintre magistrații curților marțiale ale diviziilor din subordine, aceștia urmând să plece la unitățile destinate chiar în ziua următoare.

Suntem nevoiţi să precizăm că nu toate unităţile ardelene au manifestat un spirit combativ scăzut și o stare disciplinară precară. Una dintre unitățile cu trupe recrutate exclusiv în Ardeal care făcea notă discordantă era Regimentul „Beiuş”, format exclusiv din moți, voluntari provenind din zona Brad, Baia de Criş, Câmpeni, Abrud şi Hălmagiu ${ }^{56}$.

La 18 iunie 1919, generalul Ștefan Panaitescu, șeful de stat major al Comandamentului Trupelor din Transilvania, raporta telegrafic Marelui Cartier General prestația regimentului în luptele de pe Tisa: „(...) Regimentul «Beiuş» s-a comportat foarte bine în operațiunile pe care le-a executat (...). A luat parte la atacurile de la Csucs-Borossebes-Ocsod şi s-a ilustrat în special la atacurile de la capul de pod de la Szolnok unde, susţinut de bateria Beiuş (e nominalizată bateria regimentului, s.n.) a învăluit și atacat flancul stâng al inamicului care era susținut de numeroasa artilerie așezată pe ambele maluri ale
Tisei. În acest atac Regimentul «Beiuş» a înaintat sub focurile inamicului în perfectă ordine fără a se opri $6 \mathrm{~km}$ pe un teren net (a se citi deschis, s.n.) până la baionetă. Din trupele inamice n-au mai scăpat decât acei care aveau căruțe la îndemână" ${ }^{57}$.

O posibilă explicație a acestei diferențe de atitudine pare săfi fost, pe lângă o instrucție adecvată, pregătirea morală a trupei. Înaintea plecării la luptă, au fost adunați la biserica ortodoxă din Ţebea pentru depunerea jurământului, cu drapelul regimentului înfipt pe mormântul lui Avram Iancu. Acolo, colonelul Gheorghe Rasoviceanu, comandantul Regimentului 9 vânători, le-a vorbit astfel: ,Ostaşi, grăiesc vouă astăzi sub gorunul lui Horia martirul, în faţa mormântului lui Avram Iancu, al munţilor fost rege. Grăiesc vouă astăzi în marele ceas, în supremul ceas al mântuirii Neamului nostru. Şi zic vouă: cutremure-se toate mădularile voastre în faţa memoriei tuturor acelora cari în lungul veacurilor au înălbit cu oasele lor moşia neamului în lung şi în lat să ajungem unde suntem şi ce suntem. Fiţi mândri că soarta tot pe voi, Moţilor, v-a hotărât să fiţi primii din tot Ardealul, cari să faceţi legământul de credinţă şi de jertfă pentru scumpa noastră Patrie (...)" 58 .

Regimentul se formase la Brad, în mijlocul regimentelor 9 și 10 vânători, și a intrat, încă de la început, în compunerea Brigăzii 4 vânători, luând parte la toate exercițiile, marşurile și manevrele de zi și de noapte, alături de aceștia, care se pare că au influențat atât moralul trupei, cât și al ofițerilor ${ }^{59}$, consideraţi de Comandamentul Trupelor din Transilvania a fi fost foarte buni. De altfel, generalul Ștefan Panaitescu raporta că, în perioada de 40 de zile cât au stat în contact direct cu vânătorii, între ofițerii și trupa Regimentului „Beiuş” a domnit cea mai desăvârșită armonie.

\section{Concluzii}

Din expunerea cronologică a demersurilor care au legătură cu acest subiect, reiese că, la momentul emiterii celor două acte normative, ,Decretul-Lege nr. 345", din 25 ianuarie/2 februarie 1919, respectiv, „Decizia nr. 40”, din 26 ianuarie/3 februarie 1919, Consiliul Dirigent publicase deja „Decretul I”, prin care legislația ungară, legile, ordonanțele, regulamentele și statutele legale emise înainte de 18 octombrie 1918 rămăseseră provizoriu în vigoare.

$\mathrm{Cu}$ toate acestea, nu se poate susține ideea că, în momentul elaborării proiectelor celor două 
acte normative, ministrul de război, generalul Arthur Văitoianu, ar fi fost la curent cu modul de administrare a justiției militare în diviziile ardelene, mai ales că raportul generalului Ioan Boeriu, adresat Ministerului de Război, deși datat 18 februarie 1919, fusese înregistrat la Ministerul de Război abia în data de 3 martie 1919, cu nr. 7095.

De asemenea, nimic nu ne îndreptățește să susținem ipoteza conform căreia, în situația în care ar fi cunoscut aceste aspecte, generalul Arthur Văitoianu ar fi adoptat un alt curs decât cel în care, începând cu data de 24 ianuarie/6 februarie 1919, toate regulamentele și toate legile românești cu caracter militar au devenit aplicabile și unităților din compunerea diviziilor ardelene.

Sistemul greoi de aplicare a unei justiții militare comune în cele două entităţi care formau Comandamentul Trupelor din Transilvania, și ne referim, aici, la trupele regulate din Vechiul Regat, și la diviziile ardelene din corpurile 6 și 7 armată, a avut un impact vizibil asupra stării disciplinare din unele unități ale acestora din urmă.

Slab echipate, cu o încadrare redusă a corpului ofițeresc, aspect care se regăsea mai pregnant în nivelul precar de disciplină, dar mai presus de toate, cu trupa marcată de anii lungi de război și atinse de vântul revoluției bolșevice, unele dintre aceste unități nu au confirmat, fiind retrase de pe front pentru a parcurge o perioadă de instrucție, în care au fost folosite la paza unor obiective, precum și la alte activități preponderent administrative.

Trebuie menționat că, în iunie 1919, în vederea restabilirii ordinii și disciplinei militare, au fost luate și alt gen de măsuri, pe lângă atenționarea comandanților de divizii. Astfel, la Divizia 16 infanterie s-a dispus măsura destituirii tuturor celor patru comandanți ai regimentelor de infanterie, coloneii Pompet Bersan, Carol Divisioli, Adolf Reiner și Henrich Brandsch, care au fost înlocuiți $\mathrm{cu}$ ofițeri din structurile armatei române din Vechiul Regat ${ }^{60}$.

În mod evident, Comandamentul Trupelor din Transilvania lega direct starea disciplinară a trupelor de nefuncționarea în parametri firești a justiției militare, datorată legislației neunitare şi lipsei personalului specializat, avocaţi ori magistrați de profesie, disponibili pentru a încadra curțile marțiale.

În documentarea prezentului material, am întâlnit numeroase cereri de demobilizare din partea unor ofițeri în rezervă, magistrați ori avocați în viața civilă, care invocau diverse motive pentru a fi lăsați la vatră, solicitând chiar înlocuirea cu alți magistrați care nu fuseseră încă chemați la mobilizare ori care propuneau un sistem de rotație la mobilizarea magistraților.

De altfel, chiar Ministerul de Justiţie era rezervat în a încuviința mobilizarea magistraților, din cauza multitudinii problemelor cu care se confrunta și a reformelor economice, sociale și legislative aflate în derulare, astfel încât, la solicitările repetate ale Marelui Cartier General în acest sens, răspundea, de obicei, negativ: „am stăruit la Ministerul de Justiţie în a ne pune la dispoziție un număr de 10 magistrați, ofițeri de rezervă, absolut necesari pentru complectarea curților marțiale din zona de operații, raporta generalul Gheorghe Cereșeanu, [dar] mi s-a răspuns de domnul secretar general că din cauza birourilor expropieri, despăgubiri și electorale, nu poate să aibă niciun magistrat disponibil pentru justiția militară" ${ }^{\prime \prime 1}$.

Despre diferențele legislative pe care le-am prezentat, subscriem ideii că acestea au făcut parte dintr-un proces firesc, asumat, considerăm noi, de marii oameni politici ai vremii de pe ambele părți ale Carpaților: „(...) O înlăturare bruscă a legilor și instituțiilor de drept, ce se aflau în teritoriile alipite, n-ar fi contribuit la unirea sufletească, pe care o dorește oricare patriot bun, și nici nu s-ar fi putut realiza fără mari dificultăți. Era deci inevitabil ca, pentru un timp de tranziție (...), să rămână în vigoare legile care dominau în provinciile alipite înainte de anul 1919" 62 .

Dispute pe teme de legislație între Ardeal și Vechiul Regat au mai fost; am putea cita în acest sens refuzul barourilor ardelene de a accepta, printre membrii, avocați din Vechiul Regat, din cauza diferențelor de pregătire universitară dintre cele două categorii ale aceleiași bresle, motivul fiind acela că avocații din Vechiul Regat puteau profesa după facultate, pe când omologii lor ardeleni trebuiau să aibă, pe lângă titlul de doctor în drept, și un număr de ani de practică ${ }^{63}$.

Diferențele legislative nu au fost soluţionate nici chiar după adoptarea, în anul 1923, a noii Constituțiii ${ }^{64}$, care, la art. 137 prevedea: „Se vor revizui toate codurile și legile existente în diferite părți ale statului român spre a se pune în armonie cu Constituțiunea de față și a asigura unitatea legislativă. Până atunci ele rămân în vigoare”. Abia 
în anul 1938, ca urmare a procesului de reformare a justiţiei și a legislației aferente, se poate vorbi despre unificare juridică, legislativă, administrativă și judiciară a noilor provincii în România ${ }^{65}$.

Cât despre unitățile de voluntari ardeleni, câțiva ani mai târziu, generalul Henri Cihoski scria ${ }^{66}$ că, la serbările prilejuite de ceremonia de încoronare de la Alba Iulia, generalul Dănilă Papp a prezentat Divizia 18 , în așa condițiuni”, încât a fost decorat cu Ordinul „Coroana României”, în grad de mare ofițer.

\section{NOTE:}

1 Cristina Rotaru-Radu, „Unificarea legislației penale după Marea Unire din 1918”, Conferința națională „,Dreptul românesc la 100 de ani de la Marea Unire”, Facultatea de Drept a Universității din București, 22-23 noiembrie 2018, https://drept.unibuc.ro/dyn doc/conferinta/brosura $\% 20$ conferinta $\% 20100 \% 20 \mathrm{de} \% 20 \mathrm{ani} \% 20$ update.pdf, accesat la 10.05.2021.

2 Dumitru Preda, Vasile Alexandrescu, Costică Prodan, In apărarea României Mari. Campania armatei române din 1918-1919, Editura Enciclopedică, București, 1994, p. 77.

3 *** Istoria infanteriei române, Editura Știinţifică și Pedagogică, București, 1985, vol. II, p. 149.

4 Dumitru Preda, Vasile Alexandrescu, Costică Prodan, op.cit., p. 132.

5 Ibidem, p. 91.

6 Ibidem, p. 102.

7 Ibidem, p. 131.

8 Ibidem, p. 149.

9 Ibidem.

10 Mihail E. Ionescu, coordonator, Românii în Marele Război: anul 1915. Documente, impresii, mărturii, Editura Militară, București, 2015, p. 227.

11 Ibidem, p. 228.

12 Ibidem, p. 256.

13 Ibidem, p. 229.

14 Dumitru Preda, Vasile Alexandrescu, Costică Prodan, op.cit., p. 154.

$15 * * *$ Monitorul Oficial, nr. 243, 26 ianuarie 1919, p. 4784.

16 Ibidem.

17 Glenn E. Torrey, România în Primul Război Mondial, Editura Meteor Publishing, București, 2014, p. 345.

18 Cornel Țucă, Laurențiu Batin, Ofițeri ardeleni şi bucovineni din fosta armată austro-ungară, Editura Ethnologia, Baia Mare, 2018, p. 35.

19 Dumitru Preda, Vasile Alexandrescu, Costică Prodan, op.cit., p. 156.

20 Ibidem.

21 Ibidem.

22 [AMNR], fond microfilme, Ministerul de Război, Secția a III-a justiție, FII.5.1852, dosar nr. 20, f. 453-454.

23 Ibidem, f. 453.

24 [AMNR], fond Marele Cartier General, crt. 1990, f. 118. 25 Ibidem, f. 327.

26 [AMNR], fond microfilme, Ministerul de Război, Secția a III-a justiție, FII.5.1852, dosar nr. 20, f. 450.

27 *** Gazeta Oficială, nr. 6, din 14/27 ianuarie 1919, p. 1.
28 *** Gazeta Oficială, nr. 16, din 27 februarie/ 12 martie 1919 , p. 3.

29 Teritoriul Comitatului Solnoc-Dăbâca este actualmente împărțit între județele Cluj (centrul și sudul, cu orașul Dej), Maramureș (nordul), Bistrița-Năsăud (estul) și Sălaj (vestul), https://ro.wikipedia.org/wiki/Comitatul_SolnocD\%C4\%83b\%C3\%A2ca, accesat la 07.05.2021.

30 [AMNR], Biblioteca arhivistică, crt. 1390, f. 147.

31 [AMNR], fond microfilme, Ministerul de Război, Secția a III-a justiție, FII 5.1852, ds. 49, f. 453.

32 Ibidem.

33 *** Monitorul Oficial, nr. 127, 29 august 1918, pp. 2040-2041.

34 [AMNR], fond microfilme, Ministerul de Război, Secția a III-a justiţie, FII 5.1852, ds. nr. 49, f. $453 \mathrm{v}$.

35 Ibidem, f. 450.

36 *** Gazeta Oficială, nr. 31-35, din 25-31 mai, 5, 12, 16 iunie 1919, p. 5.

37 [AMNR], fond Marele Cartier General, crt. 1990, f. 118.

38 Ibidem, f. 57.

39 Ibidem, f. 72.

40 Ibidem, f. 73

41 Ibidem, f. 59-61.

42 [AMNR], fond Marele Cartier General, crt. 1990, f. $59-61$.

43 Ibidem, crt. 2568, f. 149.

44 Ibidem, crt. 2568, f. 172.

45 Ibidem, crt. 3215, f. 88.

46 Ibidem, crt. 2568, f. 126.

47 Ibidem, crt. 2568, f. 174.

48 Ibidem, crt. 2568, f. 299.

49 Ibidem, crt. 2568, f. 332.

50 [AMNR], fond Marele Cartier General, Secția Justiție, dosar crt. 2568, f. 584.

51 Ibidem, dosar crt. 1990, f. 308.

52 Ibidem, dosar crt. 1990, f. 308.

53 Ibidem, dosar crt. 1990, f. 308v.

54 [AMNR], fond Marele Cartier General, Secția Adjutantură, dosar crt. 3215, f. 122.

55 Ibidem, dosar crt. 3215, f. 123.

56 http://enciclopediaromaniei.ro/wiki/Regimentul_de voluntari_Horea, accesat la 09.05.2021.

57 [AMNR], fond Marele Cartier General, crt. 1990, f. 111 .

58 http://enciclopediaromaniei.ro/wiki/Regimentul_de voluntari_Horea, accesat la 09.05.2021.

59 [AMNR], fond Marele Cartier General, crt. 1990, f. 112. f. 099.

60 [AMNR], fond Marele Cartier General, crt. 1990,

61 [AMNR], fond Marele Cartier General, crt. 2568, f. $185 \mathrm{v}$.

62 Cristina Rotaru-Radu, cuvânt-înainte la lucrarea Unificarea legislației penale după Marea Unire din 1918, Editura Universul Juridic, București, 2018, apud. Corneliu Chiseliță, Cuvânt-înainte la „I. Tanoviceanu - Tratat de Drept şi procedură penală, Tip. Curierul Judiciar, vol. IV”, p. 12.

63 Vasile Stăncescu, „Avocaţii din Regat și avocații din Ardeal", Curierul justiției militare, 15 martie 1922, în [AMNR], Biblioteca arhivistică, crt. 1390, f. 180. 
$64 \mathrm{http} / / /$ www.cdep.ro/pls/legis/legis_pck.htp_act text?idt=1517, accesat la 07.05.2021.

$65 \mathrm{https} / / / w w w . u n b r . r o /$ unificarea-si-integrareajuridica-a-romaniei-consecinta-a-actului-de-la-1-decembrie1918-cu-privire-speciala-asupra-transilvaniei-alocutiunesustinuta-de-dl-prof-univ-dr-ioan-santai-la-alba-iul/, accesat la 07.05.2021.

66 [AMNR], fond Direcția Cadre și Învățământ, Memorii Bătrâni, litera P, general Papp, dosar 68, f. 10.

\section{BIBLIOGRAFIE}

*** Istoria infanteriei române, Editura Științifică și Pedagogică, București, 1985.

*** Unificarea legislației și funcționarea sistemului judiciar după Mare Unire din 1918, Culegere de articole realizate de audienţii INJ şi auditorii INM, Editura Universul Juridic, București, 2018.

Ionescu Mihail E., (coordonator), Românii $\hat{\imath}$ Marele Război: anul 1915. Documente, impresii, mărturii, Editura Militară, București, 2015.

Preda Dumitru, Alexandrescu Vasile, Prodan Costică, În apărarea României Mari. Campania armatei române din 1918-1919, Editura Enciclopedică, București, 1994.

Rotaru-Radu Cristina, „Unificarea legislației penale după Marea Unire din 1918”, Conferința națională „Dreptul românesc la 100 de ani de la Marea Unire”, Facultatea de Drept a Universității din București, 22-23 noiembrie 2018, https:// drept.unibuc.ro/dyn_doc/conferinta/brosura\%20 conferinta $\% 20100 \% 20 \mathrm{de} \% 20 \mathrm{ani} \% 20$ update.pdf

Rotaru-Radu Cristina, „Unificarea legislaţiei și funcționarea sistemului judiciar după Marea Unire din 1918", Culegere de articole realizate de audienții INJ, Editura Universul Juridic, București, 2018.
Torrey Glenn E., România în Primul Război Mondial, Editura Meteor Publishing, București, 2014.

Țucă Cornel, Batin Laurențiu, Ofțeri ardeleni și bucovineni din fosta armată austro-ungară, Editura Ethnologia, Baia Mare, 2018.

*** Gazeta Oficială nr. 6, din 14/27 ianuarie 1919.

*** Gazeta Oficială, nr. 31-35, din 25-31 mai, 5, 12, 16 iunie 1919 .

*** Monitorul Oficial, nr. 243, 26 ianuarie 1919.

*** Monitorul Oficial, nr. 127, 29 august 1918.

[AMNR], fond Direcția Cadre și Învățământ,

Memorii Bătrâni, litera P, general Papp, dosar 68.

[AMNR], fond microfilme, Ministerul de Război, Secția a III-a justiţie, FII.5.1852, dosar nr. 20.

[AMNR], fond Marele Cartier General, crt. 1990.

[AMNR], fond Marele Cartier General, Secția Justiţie, dosar crt. 2568.

[AMNR], fond Marele Cartier General, Secția Adjutantură, dosar crt. 3215.

http://enciclopediaromaniei.ro/wiki/Regimen tul_de_voluntari_Horea

http://www.cdep.ro/pls/legis/legis_pck.htp_ act text?idt=1517, accesat la 07.05.2021.

https://drept.unibuc.ro/dyn_doc/conferinta/ brosura $\% 20$ conferinta $\% 20100 \% \overline{2} 0 \mathrm{de} \% 20$ ani $\% 20$ update.pdf

https://ro.wikipedia.org/wiki/Comitatul_ Solnoc-D $\%$ C4\%83b\%C3\%A2ca

https://www.unbr.ro/unificarea-si-integrareajuridica-a-romaniei-consecinta-a-actului-de-la1-decembrie-1918-cu-privire-speciala-asupratransilvaniei-alocutiune-sustinuta-de-dl-prof-univdr-ioan-santai-la-alba-iul/ 